\title{
THE ENGLISH LESSON PLAN ON THE THEME "WAR CONFLICTS: THE HUMAN COST"
}

This work is a scenario of the English lesson dealing with the discussion of one of the greatest problems humanity currently faces and comprises a set of tasks for students at the $\mathrm{C} 1$ level at English classes. These assignments and suggested activities envisage speaking, listening and reading exercises, encourage students to discuss the problem of war conflicts around the world and their consequences and organize active usage and efficient acquisition of language material.

Key words: war conflict; human cost; death; destruction; chemical weapon; regime; slaughter; international community; lesson plan; the English language; C1 level.

Слобоженко Руслан Анатолійович, старший викладач кафедри іноземних мов, факультет міжнародних відносин, Національний авіаційний університет, м. Київ, ruslan.slobozhenko@gmail.com

ПРАКТИЧНЕ ЗАНЯТТЯ 3 АНГЛІЙСЬКОї

МОВИ НА ТЕМУ «ВІЙСЬКОВІ КОНФЛІКТИ: ЦІНА ЛЮДСЬКОГО ЖИТТЯ»

Методична розробка є сценарієм практичного заняття з англійської мови, присвяченого обговоренню однієї з найактуальніших проблем людства, і містить комплекс завдань, орієнтованих на студентів рівня С1. Наведені завдання та запропоновані форми роботи, які передбачають вправляння у говорінні, аудіюванні та читанні, заохочують студентів до спілкування щодо проблеми військових конфрліктів у світі та їх наслідків, організують активне використання й ефрективне засвоєння мовленнєвого матеріалу.

Ключові слова: військовий конфолікт; ціна людського життя; смерть; руйнування; хімічна зброя; режим; масове вбиство; міжнародна спільнота; практичне заняття; англійська мова; рівень С1.

Слобоженко Руслан Анатольевич, старший преподаватель кафедры иностранных языков,

факультет международных отношений, Национальный авиационный университет, г. Киев, ruslan.slobozhenko@gmail.com

\section{ПРАКТИЧЕСКОЕ ЗАНЯТИЕ ПО АНГЛИЙСКОМУ ЯЗЫКУ НА ТЕМУ «ВОЕННЫЕ КОНФЛИКТЫ: ЦЕНА ЧЕЛОВЕЧЕСКОЙ ЖИЗНИ»}

Данная методическая разработка является сценарием практического занятия по английскому языку, посвященного обсуждению одной из наиболее актуальных проблем человечества, и содержит комплекс упражнений и заданий, рассчитанных на студентов уровня С1. Предложенные виды деятельности направлены на практику в говорении, аудировании и чтении, вовлекают студентов в общение по проблеме военных конфликтов в мире и их последствий, способствуют активному употреблению и эффективному усвоению языкового и речевого материала.

Ключевые слова: военный конфллит; цена человеческой жизни; смерть; разрушение; химическое оружие; режим; массовое убийство; международное сообщество; практическое занятие; английский язык; уровень С1.
The war is one of the serious global issues. It devastates countries. It leads sides to commit atrocities. It tears communities apart. It makes people suffer. It creates overwhelming levels of displacement and forces people to flee their homes. It leads to destitution and the destruction of cities. It leaves hundreds of thousands of people dead. The death toll is extremely high. Growing hatred and wish to retaliate tend to encourage sides for violence. The war violates the fundamental principles. Whatever its causes, it should be cause for alarm. That is why this topic is important, enables us to be involved in it and concerns students of any major.

\section{Theme: WAR CONFLICTS: THE HUMAN COST} Level: $\mathrm{C} 1$

Objectives: to improve students' skills in speaking, reading and listening comprehension; to practice thematic vocabulary and grammar.

Materials to used: article "Gasping for life: Syria's merciless war on its own children" (available at https://edition.cnn.com/2017/05/09/ middleeast/syria-chemical-attack-ward/index.html); video "Who is fighting and why?" (available at https://www.youtube.com/ watch? $\mathrm{v}=\mathrm{JFpanWNgfQY);} \mathrm{song} \mathrm{"Civil} \mathrm{War"} \mathrm{by} \mathrm{Guns} \mathrm{N'} \mathrm{Roses}$ (available at https://www.youtube.com/watch?v=isCh4kCeNYU)

1. "Warm-up": a discussion of an important issue between the teacher and students.

T: Complete the words with missing letters and pronounce them correctly.

atr_city; v_olence; mass_cre; d_vastation; annih_lation, tort_re.

T: Give the definitions of the words.

atrocity; violence; massacre; devastation; annihilation; torture.

T: Match the sentences (1-6) the words (a-f) from the list.

a) atrocity b) violence c) massacre d) devastation

e) annihilation f) torture.

1 Video filmed by a drone has emerged showing fighting in a suburb of the Syrian capital Damascus, and the scale of the in the city.

2 The findings show unrelenting ___ affects almost the entire country as US to withdraw after 18 years of war.

3 They used sleep deprivation as a form of

4 It was not until half a century later in the $\overline{1990 \text { s that }}$ these came to light and created an international scandal.

5 The My Lai_ was one of the most horrific incidents of violence committed against unarmed civilians during the Vietnam War.

6 The idea behind the nuclear deterrent is that no nation will risk by attacking another. 
T: Tell what these words have in common.

T: Today we aren't talking about natural disasters, we're talking about man-made disasters. One of the worst ones is a war conflict. Name similar 'hot spots' in the world. Think about the tragedy in Syria.

\section{Watching video 1}

T: Watch the video "Syria's war: who is fighting and why?" and be prepared to answer these questions:

1. How did the conflict start? Why did it start?

2. What is the war about? Why is it a mess? Which sides are involved? Who backs them? Why?

3. What did conflict spawn?

4. What is horrifying about this war?

5. What is the message from Assad's regime?

6. Did it deliberately use chemical weapons against its own population?

https://www.youtube.com/watch?v=JFpanWNgfQY

\section{Discussing video 1}

T: Give your answers.

\section{Reading comprehension. Understanding the main} points

T: Read the article "Gasping for life: Syria's merciless war on its own children" and say whether these statements are true (T) or false $(F)$ :

1 Witnesses say government jets bombed the town, the strikes releasing a poisonous gas that would kill 82 people in all.

2 This is not the first time that the regime of Syrian President Bashar al-Assad has gassed its own people, or denied doing so.

3 The ruthless cynicism of Assad's regime, bolstered by financial and military support from Iran, the USA and the Lebanese militia Hezbollah, has left the international community horrified and paralyzed.

4 It has been clear for quite some time that the Syrian regime has no respect for human life.

5 Chemical weapons have been outlawed since the end of World War Two.

\section{Gasping for life: \\ Syria's merciless war on its own children}

A) She stares off into the distance as she gasps for air, her tiny chest heaving desperately to take in more oxygen. Her eyes are wide and unflinching, her pupils constricted, the panic behind them clear. The little girl looks confused: she doesn't understand why she is dying, why she is lying in the back of a truck with other small children, some foaming at the mouth, others motionless, the life already gone from them. The ground all around her is strewn with bodies, some wracked with convulsions, thrashing around in the mud as rescue workers attempt in vain to hose off the chemical agent that has blanketed them.
Minutes earlier it had been a typically cool morning in northern Syria. The people of Khan Sheikhoun would have been eating their breakfast, getting ready for school, playing outside or still sleeping. But shortly before 7:00 a.m. on the first Tuesday in April, witnesses say government jets bombed the town, the strikes releasing a poisonous gas that would kill 92 people in all. Video footage of the aftermath of the attack, obtained by $\mathrm{CNN}$, reveals the unsanitized view of what happened that day, and it is extremely difficult to watch. Terms like "war crimes" and "crimes against humanity" are bandied about on an almost weekly basis when it comes to Syria, abstract concepts that are often weighed down with convoluted language related to the geopolitical machinations of the conflict. Yet when you watch these children choking on what were likely their last breaths, you understand what evil is.

B) I have traveled to Syria roughly a dozen times since the civil war began in 2011, and every trip brings with it fresh images of death and destruction that leave an imprint on the brain. The petrifying thud of artillery landing late into the night. The sickening wake-up call of fighter jets wheeling overhead. The frantic search for survivors in the rubble. Women wailing over their dead brothers and husbands. The blank eyes of a young boy killed in the crossfire. The solemn march of a casket to the graveyard.

But there is something particularly horrifying about the images in Khan Sheikhoun, something uniquely haunting about watching the last gasps of innocent people. Chemical weapons have been outlawed since the end of World War One. They are barbaric and inhuman, a "red line" that should never be crossed. They also make no distinction between soldiers and children. There is no mercy, no quick death, no dignity in those last moments. The victims lose control of their faculties, froth at the mouth, and writhe around on the ground as the life drains out of them.

C) This is not the first time that the regime of Syrian President Bashar al-Assad has gassed its own people, or denied doing so. In 2013 a sarin attack left more than 1,400 dead, including more than 400 children, and a recent report by Human Rights Watch found that government forces have used nerve agents on at least four occasions in recent months. But Assad didn't just deny the regime was behind the attack in Khan Sheikhoun. He denied that it happened at all, describing it as " $100 \%$ a fabrication," as if anyone could fake the agonizing deaths captured in these images. It has been clear for quite some time that the Syrian regime has no respect for human life. For six years, it has brutalized its own people in an attempt to win back control of the country. Assad has cast the conflict as a war on terrorism. To people living in opposition-controlled areas, however, it feels more like a war on normalcy.

D) The message from the regime is clear: we will bomb your hospitals, your markets, your bakeries and your schools; we will kill your children, your mothers and your brothers. We will starve, imprison, torture and gas you, until it is no 
longer possible for any life to exist in these areas. In one Damascus suburb that was under siege, a streak of graffiti on a wall summarized the policy: "Starve or kneel [to Assad]." The ruthless cynicism of Assad's regime, bolstered by financial and military support from Iran, Russia and the Lebanese militia Hezbollah, has left the international community horrified and paralyzed.

After the genocide in Rwanda and the massacre in Srebrenica, the United Nations promised the world "never again." But geopolitical realities have a way of smashing idealistic platitudes. The international community has failed to come to any consensus about who the guilty parties are in Syria's war and how to move forward.

E) The US missile strikes on the air base from where the Khan Sheikhoun attack is believed to have been launched may have served as a powerful warning. Perhaps Assad will think twice before using sarin gas again. But the bombing hasn't stopped. Hospitals are still being targeted, and innocents are still dying. History will not be kind to world leaders for allowing the slaughter of the Syrian people to continue.

More than 20 members of the Youssef family were killed in the attack on Khan Sheikhoun. Among them was Yasser al-Youssef, a 39-year-old man who owned a supermarket and volunteered at the local mosque. Friends say Yasser, like most fathers, was very concerned about whether his children would be able to obtain a proper education in Syria.

F) Two of Yasser's boys, Muhammed, 12, and Amer, 4, also died in the attack. Muhammed loved to play soccer when it was safe enough to play outside, a cousin told CNN. Amer, on the other hand, preferred to chase chickens and doves around the family's property. A photograph taken in a happier time shows them hugging and smiling into the camera, Muhammed's arm wrapped protectively around his little brother.

Their mother, 36-year-old Sana Haj Ali, was killed too. A relative told $\mathrm{CNN}$ she was watching Amer playing outside through the window when the Syrian plane dropped its chemical payload.

Sana saw Amer fall to the ground and screamed at Yasser to rescue him. Yasser ran outside, picked up Amer and managed to climb into their car before succumbing to the effects of the gas. Sana ran out after them, and she dropped dead just outside the entrance of their home. Sana is one of thousands of mothers who have died in Syria while trying to protect their children. Amer and Muhammed are among the thousands of innocent children who have been killed in this senseless war.

G) There is nothing exceptional about these people. In many ways, they are just like us. We can't do anything to bring them back from the dead. We can't stop the nightmares, or stem the grief of those who survived. Perhaps the least we can do is to pay attention.

(https://edition.cnn.com/2017/05/09/middleeast/syria-chemicalattack-ward/index.html)

\section{Post-reading activities.}

T: Discuss these questions.

1 What is the human cost of conflict?

2 Will the war in Syria ever end?

3 What is the role of the international community in the conflict? Is there a solution? What is to be done?

\section{Learning and practicing vocabulary}

Definitions
T: Match these words (1-10) from the article with their meanings $(a-j)$.
1 unflinching
bandied
a) extremely good
3 massacre
b) done or arranged in a hurry
uniquely
c) make large twisting movements with the body
d) not frightened of or not trying to avoid something dangerous or unpleasant
5 brutalize e) talked about something without careful consid- eration
6 militia f) the piles of broken stone and bricks
7 smashing g) in a way that is unusual
8 writhe $\quad$ h) an act of killing a lot of people
9 frantic i) treat someone in a cruel and violent way
10 rubble j) a military force that operates only some of the time

T: Find words and expressions in the article which fit these meanings.

1 to breathe loudly and with difficulty, trying to get more air (paragraph A)

2 staying in the mind (paragraph B)

3 supported (paragraph D)

4 natural ability, such as hearing, seeing, or thinking (paragraph B)

5 the killing of many people cruelly and unfairly, especially in a war (paragraph E)

6 frightening sound that is made when something heavy falls or hits something else (paragraph B)

7 died suddenly and unexpectedly (paragraph F)

8 very shocking (paragraph B)

9 moving from side to side in a violent or uncontrolled way (paragraph A)

$\mathbf{1 0}$ have a strong and lasting effect on (paragraph B)

\section{Word partnerships}

T: Match these words to make adjective-noun partnerships from the article.

$\begin{array}{ll}1 \text { convoluted } & \text { a) cynicism } \\ 2 \text { senseless } & \text { b) view } \\ \mathbf{3} \text { solemn } & \text { c) language } \\ \mathbf{4} \text { geopolitical } & \text { d) march } \\ \mathbf{5} \text { unsanitized } & \text { e) war } \\ \mathbf{6} \text { ruthless } & \text { f) machinations }\end{array}$

\section{Text completion}

T: Complete the text with the words and expressions without using the article.

She stares off into the distance as she 1) for air, her tiny chest heaving desperately to take in more oxygen. Her eyes are wide and 2) , her pupils constricted, the panic behind them clear. The little girl looks confused: she doesn't understand why she is dying, why she is lying in the back of a truck with other small children, some foaming 
at the mouth, others motionless, the life already gone from them. The ground all around her is strewn with bodies, some wracked with convulsions, 3 ) around in the mud as rescue workers attempt in vain to hose off the chemical agent that has blanketed them.

... Video footage of the aftermath of the attack, obtained by $\mathrm{CNN}$, reveals the 4 ) view of what happened that day, and it is extremely difficult to watch. Terms like "war crimes" and "crimes against humanity" are 5) about on an almost weekly basis when it comes to Syria, abstract concepts that are often weighed down with 6)____ language related to the geopolitical 7) of the conflict. Yet when you watch these children choking on what were likely their last breaths, you understand what evil is.

I have traveled to Syria roughly a dozen times since the civil war began in 2011, and every trip brings with it fresh images of death and destruction that leave an 8) on the brain. The 9) thud of artillery landing late into the night. The sickening wake-up call of fighter jets wheeling overhead.

But there is something particularly horrifying about the images in Khan Sheikhoun, something uniquely 10) about watching the last gasps of innocent people.

Chemical weapons have been 11) since the end of

World War One. They make no distinction between soldiers and children.

There is no mercy, no quick death, no 12) in those last moments. The victims lose control of their 13) froth at the mouth, and 14) around

on the ground as the life drains out of them.

It has been clear for quite some time that the Syrian regime has no respect for human life. For six years, it has 15) control of the country. its own people in an attempt to win back The 16)

17) cynicism of Assad's regime, Russia and the Lebanese 18) international community 19) support from Iran, the genocide in Rwanda and the 20) and paralyzed. After the United Nations promised the world "never again." But geopolitical realities have a way of smashing idealistic 21) . The international community has failed to come to any consensus about who the guilty parties are in Syria's war and how to move forward.

History will not be kind to world leaders for allowing the 22) of the Syrian people to continue.

\section{Listening to the song}

T: Listen to the part of the song by a famous American rock group, Guns N'Roses. Complete the gaps and guess the name of the song. There are 3 options to choose from: Déjà vu, Civil war, Fighting.

What is the main idea of the song? Do you support it?
What we've got here is to communicate. Some men you can't just reach ...

So, you get what we had here last week, which is the way he wants it!

Well, he gets it! N' I don't like it any more than you men.

Look at your young men fighting, look at your women crying, Look at your young men dying, the way they've always done before,

Look at the hate we're , look at the fear we're

Look at the lives we're , the way they've always done before.

My hands are tied, the shift from side to side,

And the go on with God and our rights,

And all these things are swept aside by pride, for the love of can't deny,

And are washed away by your the of our civil wars. hands time

D'you wear a black armband when they shot the man, who said ' could last forever',

And in my memories they shot Kennedy, I went when I learned to see,

So I never fell for Vietnam, we got the wall of D.C. to remind us all,

You can't trust when it's not in your hands, when everybody's fighting for their promised

And I don't need your civil war

It _____ the rich while it _____ the poor

Your power hungry selling soldiers in a human grocery store, ain't that fresh

I don't need your civil war

(https://www.youtube.com/watch?v=isCh4kCeNYU)

\section{Discussing the song}

T: Give your answers.

\section{Summary}

T: Divide into three groups, recap what we have learned about war conflicts and present it to the class. Give your answers.

T: Why do we raise this serious issue? Because we have to remember that we are humans and have to be humane. And I quote Saadi "He who is indifferent to the suffering of others is a traitor to that which is truly human."

\section{REFERENCES}

1. CNN International. Gasping for life: Syria's merciless war on its own children. Retrieved: https://edition.cnn.com/2017/05/09/middleeast/ syria-chemical-attack-ward/index.html .

2. Syria's war: who is fighting and why? Retrieved: https://www.youtube.com/watch? v=JFpanWNgfQY .

3. Guns N' Roses. Civil War. Retrieved: https://www.youtube.com/ watch?v=isCh4kCeNYU .

Отримано 20.01.2020 